\title{
The Soft Drinks Case: The WTO and Regional Agreements*
}

\author{
WILLIA M J. D A VEY \\ Professor of Law (Retired), University of Illinois College of Law \\ ANDRÉ SAPIR \\ Professor of Economics, ECARES, Universite Libre de Bruxelles, Brussels \\ Senior Fellow, Bruegel, Brussels and Research Fellow, CEPR, London
}

The Mexico - Soft Drinks case ${ }^{1}$ arose out of a larger dispute between the United States and Mexico concerning the market for sweeteners in North America. We begin with a bit of background - examining the US regulation of its sweetener market and its effect on the markets for sugar and an alternative sweetener known as high-fructose corn syrup (HFCS). We then examine the dispute over what NAFTA provided in respect of sweeteners and how Mexico responded to the US refusal to submit their dispute to a NAFTA dispute settlement Panel. Following this background section, we briefly consider the substance of the US case under GATT Article III and Mexico's defense under GATT Article XX(d), in respect of which the Appellate Body's decision was not particularly controversial or noteworthy. We then turn to the interesting issues raised by the case. First, in what circumstances, if any, can a Panel decline to exercise jurisdiction in a matter that is properly before it? Second, to what extent can a Panel consider other international agreements? Third, and more generally, how can the interests of non-party WTO Members best be protected in disputes between parties to a preferential trade agreement?

\section{Background}

The United States has a strictly controlled import regime for sugar. ${ }^{2}$ Since US production of sugar is inadequate to meet US needs, the US must allow sugar

\footnotetext{
* Comments on an earlier version by the discussant, Frieder Roessler, and by Chad Bown, David Gantz, Bernard Hoekman, Joost Pauwelyn, Joel Trachtman, and Joseph Weiler are gratefully acknowledged.

1 Appellate Body Report, Mexico - Tax Measures on Soft Drinks and Other Beverages, WT/DS308/ AB/R, adopted 24 March 2006, and Panel Report, WT/DS308/R, adopted as modified by the Appellate Body Report. The Appellate Body division consisted of Yasuhei Taniguchi (presiding), Merit E. Janow, and Giorgio Sacerdoti. The Panel was composed with the agreement of the parties and consisted of Ronald Saborio Soto (chair), Edmond McGovern, and David Walker.

2 For a description of the US import regime, see United States Department of Agriculture - Foreign Agricultural Service, 'Fact Sheet: US Imports of Sugar and Sugar-Containing Products' (March 2007), available at http://www.fas.usda.gov/info/factsheets/ussugar.pdf (last visited 6 October 2008). For US sugar policy more generally, see United States Department of Agriculture - Economic Research Service, 'Briefing Rooms: Sugar and Sweeteners: Policy' (3 March 2008), available at http://www.ers.usda.gov/ Briefing/Sugar/Policy.htm (last visited 6 October 2008).
} 
imports. However, it has traditionally limited such imports so as to produce a US market price for sugar that is much higher than the international market price. The aim is to achieve a price level that is sufficient to allow US sugar-beet and sugarcane producers to operate at a profit, so that the US government price-support program for sugar can operate on a no-cost basis. High US sugar prices have led over the years to increased US production of alternative sweeteners, notably HFCS, which has largely replaced sugar as a sweetener in certain products, especially soft drinks, in the United States.

Mexico and the United States (as well as Canada) are parties to the North American Free Trade Agreement (NAFTA). According to Mexico, ${ }^{3}$ Annex 703.2(A) of NAFTA would permit Mexico, starting in 2000, to export sugar to the United States up to the amount of its net production surplus of sugar if it achieved a net production surplus for two consecutive years. Subsequent to the conclusion of the basic NAFTA negotiations, there were further negotiations that resulted in two side letters (one in English and one in Spanish) that were initialed by the principal negotiators for the two countries. These letters would have deleted the provision in the Annex (paragraph 16) that permitted Mexican exports up to the amount of its net production surplus of sugar, leaving in place a provision that imposed quantitative limits on such exports (paragraph 15). According to Mexico, the letters were never signed by the appropriate ministers as intended, and the parties later exchanged letters in which they disagreed as to whether the two described side letters had become part of NAFTA.

The evolution of the US - Mexico sweetener market after NAFTA entered into force in 1994 can be briefly described as follows. There was an expectation in Mexico that in the near future it would be able to export significant new quantities of sugar to the US market. That expectation was thwarted given the US view of the effect of the side letters. Moreover, under NAFTA, US exports of HFCS to Mexico increased significantly, thereby reducing the Mexican domestic market for Mexican sugar. This obviously resulted in problems for the Mexican sugar industry, exacerbated by Mexico's domestic sugar policy, which had kept Mexican sugar prices somewhat above US prices and much above world prices. ${ }^{4}$ Mexico attempted to take the matter to NAFTA dispute settlement in 2000, but since the roster of panelists for NAFTA Chapter 20 proceedings had never been agreed, Mexico needed the cooperation of the United States in order to have the Panel composed, and the US did not cooperate. ${ }^{5}$ Thus, Mexico was unable to obtain a

3 The Mexican version of the background to the dispute is taken from the Panel report, paras. 4.77-4.97.

4 For a similar view of the evolution of the NAFTA sugar market, see United States Department of Agriculture - Foreign Agricultural Service, 'Mexico and Sugar: Historical Perspective', available at http://www.fas.usda.gov/htp/sugar/2004/History\%20of\%20sugar\%20dispute\%20final.pdf (last visited 6 October 2008).

5 One of the problems of the GATT dispute settlement system was that it could be blocked if the disputing parties did not agree on the composition of the Panel (i.e. on the identity of the panelists). The 
NAFTA Panel ruling on its claims that it was being denied the access to the US sugar market provided for in Annex 703.2(A).

Also during this time period, Mexico initiated an antidumping investigation of US exports of HFCS to Mexico. This led to the imposition of AD duties on US HFCS exports as of 25 June 1997, at first provisionally and later on a definitive basis. ${ }^{6}$ The US successfully challenged the duties in both regular and compliance proceedings at the WTO, ${ }^{7}$ but the duties were not revoked until May 2002. Effective as of 1 January 2002, Mexico adopted the measure at issue in this case - a $20 \%$ tax on soft drinks and other beverages that use any sweetener other than cane sugar. ${ }^{8}$ The effect of the tax was to eliminate almost all exports of HFCS from the United States to Mexico. ${ }^{9}$ After the March 2006 WTO ruling that the tax violated Article III and could not be justified under Article XX(d), Mexico removed the tax as of January $2007 . .^{10}$

In July 2006, the US and Mexico reached an agreement on various sweetener trade issues - including the removal of the tax at issue in this dispute. ${ }^{11}$ As of

WTO solves this problem by providing that the WTO Director-General can appoint the members of a Panel if the parties cannot agree. NAFTA attempted to solve this problem by providing for a 30-person roster of panelists - with ten from each party. NAFTA, art. 2009. Under NAFTA article 2011, five-person Panels are to be composed as follows: the chair is to be agreed upon and each party is to select two panelists who are from the other party (normally from the roster since anyone else would be subject to preemptory challenge). If the chair is not agreed upon, then the party chosen by lot is to select the chair. If a party does not select its panelists, they are to be chosen by lot from the roster. The roster has never been formally established.

6 For a description of the evolution of this dispute, see William J. Davey, 'Implementation of the Results of WTO Trade Remedy Cases', in The WTO Trade Remedy System: East Asian Perspectives (Mitsuo Matsushita, Dukgeun Ahn, and Tain-Jy Chen eds., London: Cameron May 2006), pp. 33, 51-52.

7 Mexico - Anti-Dumping Investigation of High Fructose Corn Syrup from the United States, WT/ DS132/R, adopted 24 February 2000; Mexico-Anti-Dumping Investigation of High Fructose Corn Syrup (HFCS) from the United States, Recourse to Article 21.5 of the DSU by the United States, WT/ DS132/RW \& AB/RW, adopted 21 November 2001. The duties were also successfully challenged in NAFTA Chapter 19 proceedings. Final Decisions, Review of the Final Determination of the Antidumping Investigation on Imports of High Fructose Corn Syrup, Originating from the United States of America, Case MEX-USA-98-1904-01, 3 August 2001 and 15 April 2002.

8 The measure is described more precisely in the Panel report, at paras. 2.1-2.6.

9 The effect of the tax was felt almost exclusively by the United States, although the tax did not discriminate explicitly on the basis of origin. Mexico is a very minor producer of HFCS ( $1 \%$ of world production in 2004), while the US is the overwhelmingly dominant producer ( $71 \%$ of world production) and had preferential access to the Mexican market under NAFTA. Paul Bratley, 'The Ups and Downs of Corn Sweeteners', International Sweetener Colloquium, Tucson, Arizona, 7 February 2005 (available at http://www.idfa.org/meetings/presentations/paul_bratley_presentation.ppt\#427,4,2004 HFCS Production by Country (last visited 6 October 2008)).

$10 \mathrm{WT} / \mathrm{DS} 308 / 16$.

11 The text of the so-called Sweeteners Agreement with Mexico can be found at http://www.ustr.gov/ assets/Trade_Agreements/Regional/NAFTA/asset_upload_file694_10810.pdf (last visited 6 October 2008). The HFCS-sugar dispute between the US and Mexico is described in general in Gary Clyde Hufbauer and Jeffrey J. Schott, NAFTA Revisited: Achievements and Challenges, pp. 243-245 (Institute of International Economics 2005). The settlement did not resolve several NAFTA Chapter 11 (Investment) disputes brought by US HFCS makers against Mexico. Reportedly, a Panel in one of those cases has found that Mexico is liable for a violation of the national-treatment provision of Chapter 11, but has not yet set 
1 January 2008, the NAFTA transitional arrangements for sweeteners ended, and trade in sweeteners between Mexico and the US has been tariff- and quota-free since that date, although there have been proposals to reregulate it by the sugar industries on both sides, opposed by the HFCS industry. ${ }^{12}$

\section{The substantive issues in Soft Drinks}

\subsection{GATT Article III}

The United States argued that the soft-drinks tax (and a related tax on the distribution of beverages subject to the soft-drinks tax) violated both sentences of GATT Article III:2, which essentially prohibits (i) internal taxes on imported products in excess of those applied to like domestic products (first sentence) and (ii) internal taxes on imported products where directly competitive or substitutable domestic products are not similarly taxed, so as to afford protection to them (second sentence). The US also claimed that the taxes and a related record-keeping requirement violated GATT Article III:4. Mexico conceded that the products at issue were substitutable ${ }^{13}$ and stated that it would not respond to the US claim under Article III, ${ }^{14}$ although it noted that it had legitimate objectives for enacting the challenged measure. ${ }^{15}$ After a rather detailed analysis of the issues, the Panel found that the challenged taxes violated Articles III :2 and III $: 4,{ }^{16}$ and its findings on Article III were not appealed.

\subsection{GATT Article XX $(d)$}

Mexico argued that notwithstanding the violation of Article III, the taxes could be justified under Article XX(d), which permits WTO Members to impose measures

the amount of liability. See Corn Products International's 2008 Form 10-K filing, item 3, available at http://sec.edgar-online.com/2008/02/29/0000950137-08-003051/Section10.asp (last visited 6 October 2008).

12 'USTR, USDA Reject NAFTA Proposals By U.S., Mexican Industry for Sugar Trade', BNA International Trade Daily, 11 February 2008.

13 Panel Report, para. 4.113.

14 Panel Report, para. 4.115.

15 Panel Report, para. 4.114.

16 Panel Report, paras. 8.21-8.160. In respect of sweeteners, the Panel found (i) that beet sugar and cane sugar were like products in terms of Article III:2, first sentence, and that the soft-drinks tax and distribution tax indirectly taxed imported beet sugar in excess of domestic cane sugar; (ii) that imported HFCS and domestic cane sugar were competitive products in terms of Article III:2, second sentence, and the interpretative note thereto, that they were dissimilarly taxed, and that the soft drinks and distribution taxes were applied so as to provide protection to the Mexican domestic production of cane sugar; and (iii) that beet sugar and HFCS were like products to cane sugar for purposes of Article III:4 and that the challenged soft drinks and distribution taxes and bookkeeping requirements resulted in less favorable treatment of imported beet sugar and HFCS as compared to domestic cane sugar. In respect of soft drinks and syrups, the Panel found that the imported and domestic products were like products for purposes of Article III:2, first sentence, and that the imported products sweetened with non-cane sweeteners were taxed in excess of the like domestic products. 
that are 'necessary to secure compliance with laws or regulations which are not inconsistent with the provisions of [GATT]'. Mexico argued that to invoke Article $\mathrm{XX}(\mathrm{d})$, it had to show that the taxes were designed to secure compliance with a GATT-consistent provision and were necessary to secure such compliance. ${ }^{17}$ In its view, NAFTA was the GATT-consistent provision with which it was trying to secure compliance.

In analyzing Mexico's GATT Article XX(d) defense, the Panel found first that Article $\mathrm{XX}(\mathrm{d})$ was concerned with enforcement action at the domestic, not international, level ${ }^{18}$ and that accordingly the phrase 'to secure compliance in Article $\mathrm{XX}(\mathrm{d})$ does not apply to measures taken ... in order to induce another [WTO] member to comply with its obligations ... under a non-WTO treaty' ${ }^{19}$ Second, the Panel found that Mexico had failed to explain how its measure would make any significant contribution to securing compliance by the US with its NAFTA obligations and more generally took the view that 'the outcome of international countermeasures ... is inherently unpredictable, and that they are therefore not eligible to be considered measures 'to secure compliance' within the meaning of Article XX(d)' ${ }^{20}$ Finally, the Panel found that the words 'laws and regulations', because of their place in Article $\mathrm{XX}(\mathrm{d})$ and in light of its first conclusion, 'refer to enforcement action within a particular domestic legal system, and that they do not extend to international action of the type taken by Mexico'.21

In the Appellate Body's discussion of the Article XX(d) issue, it saw the 'central issue' as being whether the terms 'laws or regulations' encompassed 'another WTO Member's obligations under an international agreement' ${ }^{22}$ The Appellate Body concluded that the terms did not encompass such obligations. While this seems to be the correct interpretation, the reasoning of the Appellate Body was not exemplary. Initially, it asserted without citing any authority that ' $\mathrm{t}$ ] he terms 'laws or regulations' are generally used to refer to domestic laws or regulations' (emphasis added), noting that past disputes involving Article $\mathrm{XX}(\mathrm{d})$ had involved domestic measures. ${ }^{23}$ It mentioned that international obligations could be transformed into domestic laws, either through domestic legislation or regulatory acts

17 Panel Report, para. 4.118, citing the Appellate Body Report in Korea-Beef, WT/DS161.

18 Panel Report, para. 8.179.

19 Panel Report, para. 8.181.

20 Panel Report, para. 8.186.

21 Panel Report, para. 8.194.

22 Appellate Body Report, para. 68. Although its determination of the scope of the terms 'laws or regulations' effectively disposed of Mexico's Article XX(d) defense, the Appellate Body also discussed the meaning of the phrase 'to secure compliance'. In that regard, it noted that while it has said that the contribution that a measure makes to securing compliance is a factor to be weighed in deciding whether it is necessary under Article XX(d), that does not mean that a measure has to guarantee that compliance will occur as suggested by the Panel or that it has to be coercive. In the Appellate Body's view, the issue is the extent to which 'the design of the measure contribute[s]' to securing compliance. Appellate Body Report, para. 74.

23 Appellate Body Report, para. 69. 
or through the practice of giving such obligations direct effect within a domestic legal system without any implementing legislation. ${ }^{24}$ But it never explained why the terms themselves could not also encompass international obligations. Nonetheless, it concluded categorically that, as used in Article $\mathrm{XX}(\mathrm{d})$, the terms 'laws or regulations' did not encompass another WTO Member's obligations under an international agreement. ${ }^{25}$

The Appellate Body's contextual argument was somewhat more persuasive. It found two GATT articles - Article X:1 and Article XX itself - where the terms 'laws' and/or 'regulations' were used and where there was a reference in another part of the provision to international agreements or obligations. ${ }^{26}$ This suggests that the drafters generally distinguished international agreements from the terms 'laws' or 'regulations'. Moreover, the Appellate Body accepted the US argument that if Mexico's interpretation were accepted, a WTO Member could invoke Article $\mathrm{XX}(\mathrm{d})$ to justify measures taken to secure compliance with another Member's WTO obligations - without complying with the detailed rules for doing so that are found in DSU articles 22 and 23. ${ }^{27}$ The persuasiveness of this argument is undercut by the fact that principles of effective treaty interpretation could obviously preclude such a result in the case of WTO obligations. The Appellate Body further noted that if Mexico's position were accepted, it would mean that the WTO dispute settlement system would have to assess whether the international agreement at issue had been violated, which would inappropriately make it an adjudicator of a non-WTO dispute, which is not its function. ${ }^{28}$ As discussed in more detail below, this argument is not really accurate, as the WTO system would only be taking a view on the other agreement to the extent it was necessary to determine WTO rights and obligations; its view would not constitute adjudication of the dispute under the other agreement. ${ }^{29}$

While its reasoning was not always that persuasive, the Appellate Body seemed to have reached the correct result. In particular, the way in which the terms 'laws or regulations' are used in GATT does seem to indicate that domestic laws and regulations are what are referred to. Surprisingly, the Appellate Body did not emphasize the ordinary meaning of these terms. Its favorite dictionary's definitions certainly are consistent with a limitation to domestic matters. ${ }^{30}$ In contrast, one

24 Appellate Body Report, para. 69 \& n.148.

25 It found support for this conclusion in the fact that the measures given as examples in Article XX(d) included only domestic measures. Appellate Body Report, para. 70. Since the examples are not exclusive, they do not themselves rule out the inclusion of international obligations within the scope of the terms.

26 Appellate Body Report, para. 71.

27 Appellate Body Report, para. 77.

28 Appellate Body Report, para. 78.

29 See text accompanying notes 60-68 infra.

30 In the New Shorter Oxford English Dictionary (1993), the first meaning of 'law' refers to ' $\mathrm{t}]$ he body of rules ... which a particular State or community recognizes'. The term 'community' could obviously be used in an international context, e.g. the community of nations, but it is probably more commonly used to refer to a more localized entity. 
generally speaks of international law, not international laws. Indeed, article 38 of the statutes of the International Court of Justice refers to international law singular - which it states is found in conventions, customs, principles, judicial decisions, and certain teachings. It does not refer to international laws or regulations. Thus, the Appellate Body's interpretation of Article XX(d)'s terms 'laws or regulations' seems consistent with the common usage, i.e. the ordinary meaning, of those terms. ${ }^{31}$

\section{Can Panels decline to exercise jurisdiction?}

In its initial submission, Mexico asked the Panel to decline to exercise jurisdiction, arguing that the matter should be referred to a NAFTA Panel. The Panel refused to do so. In its view, the DSU did not permit a Panel to decide not to exercise jurisdiction in a case properly before it. Moreover, it noted that even if it had such discretion, Mexico had not made out a proper case for exercising such discretion so as to decline jurisdiction. ${ }^{32}$ Indeed, it appeared that Mexico's basic argument was that the matter should be heard by a NAFTA Panel because only such a Panel could completely resolve the dispute - which was essentially saying that a NAFTA Panel could hear Mexico's NAFTA claims, while a WTO Panel could not. Given the injunction in DSU article 3.10 that 'complaints and counter-complaints in regard to distinct matters should not be linked', the Panel did not find this argument to be very persuasive..$^{33}$

The Appellate Body started its analysis of this issue by noting, (i) that Mexico did not contest that the Panel had jurisdiction over the US claim and (ii) that there was no legal obligation under NAFTA (or any other international agreement to which the US and Mexico were parties) that might raise 'legal impediments to the Panel hearing this case' ${ }^{34}$ Interestingly, the Appellate Body, in a footnote, ${ }^{35}$ discussed the Argentina - Poultry Anti-Dumping Duties case, ${ }^{36}$ where Brazil brought a WTO challenge to an Argentine antidumping measure that it had previously challenged unsuccessfully in Mercosur dispute settlement proceedings. The Panel in the Argentina Poultry case seemed to speculate that a not-yet-in-force Mercosur provision, which provided that once a party had brought a case under Mercosur, it

31 Marceau notes that this reading of Article XX(d) should not limit the ability of WTO Members to take environmental measures, which are more the province of subparagraphs (b) and (g) of Article XX, but that interpreting $\mathrm{XX}(\mathrm{d})$ so as to permit general countermeasures to enforce other agreements would go too far. Gabrielle Marceau, 'The Scope of the Article XX(d) Exception for Implementing MEAs Domestically and for Policing Compliance of International Environmental Laws by Other Members after the Soft Drinks Dispute' (2006), available at http://www.ictsd.org/dlogue/2006-05-30/dialogue_materials/ Gabrielle_Marceau_speaker_notes.pdf (last visited 4 June 2008).

32 Panel Report, Annex B.

33 Panel Report, paras. 7.11-7.17.

34 Appellate Body Report, para. 44.

35 Appellate Body Report, n.86.

36 Argentina-Definitive Anti-Dumping Duties on Poultry from Brazil, WT/DS241/R, adopted 19 May 2003. 
could not bring a WTO case regarding the same subject matter (and vice versa), might constitute an impediment to a WTO Panel's exercise of jurisdiction. ${ }^{37}$ Since the new Mercosur provision was not yet in force, the Panel found that there was no such impediment to its exercise of jurisdiction. Whether the Appellate Body would give effect to such a provision on mandatory choice of forum is not clear, but it seems to be a clear possibility. The issue is discussed below in more detail.

As to the instant case, the Appellate Body accepted Mexico's argument that Panels have certain powers inherent in their adjudicative function. In particular, it noted such powers as (i) the power to determine whether the Panel has jurisdiction and the scope of such jurisdiction, (ii) the discretion to deal with procedural issues that arise and that are not otherwise regulated by the DSU, and (iii) the ability to exercise judicial economy. ${ }^{38}$ But based on its view that Panels cannot disregard or modify explicit provisions of the DSU, ${ }^{39}$ the Appellate Body took the position that a Panel with jurisdiction could not decline to exercise it at all, absent some legal impediment. In the Appellate Body's view, DSU articles 3.2, 7.1, 7.2, 11, 19.2, and 23 supported this conclusion. For example, it noted that DSU article 7 instructs Panels (with standard terms of reference) to examine the matter presented, to make findings, and to address the relevant WTO provisions cited by the parties. ${ }^{40} \mathrm{~A}$ Panel that declined to exercise jurisdiction would not have complied with these directives. Nor would such a Panel have made an objective assessment of the matter as required by DSU article $11 .^{41} \mathrm{~A}$ refusal to exercise jurisdiction would also frustrate the goal of DSU article 23, which is to require Members to refer their WTO disputes to WTO dispute settlement. ${ }^{42}$ Indeed, the Appellate Body concluded that DSU article 3.3, which provides that prompt settlement of disputes is essential to the effective functioning of the WTO in situations where a Member considers that its benefits are being impaired, implies that a WTO Member 'is entitled to a ruling by a WTO panel' in such a situation. ${ }^{43}$ While this last conclusion seems overbroad, the general conclusion that Panels with jurisdiction should make basic rulings on a case seems correct, subject to the caveat that there is no legal impediment that would cause a different result. ${ }^{44}$

37 Argentina-Poultry Anti-Dumping Duties, para. 7.38.

38 Appellate Body Report, para. 45.

39 Appellate Body Report, para. 46, quoting Appellate Body Report, India-Patent Protection for Pharmaceutical and Agricultural Chemical Products, WT/DS50/AB/R, para. 92, adopted 16 January 1998.

40 Appellate Body Report, paras. 48-49.

41 Appellate Body Report, para. 51.

42 Appellate Body Report, paras. 52-53, citing also DSU articles 3.2, 3.3, and 19.2.

43 Appellate Body Report, para. 52 (emphasis original).

44 Although not mentioned by the Appellate Body, this is in accord with its earlier decisions in India-Quantitative Restrictions and Turkey-Textiles, where it rejected suggestions that certain political issues (e.g., the application of the exceptions for balance-of-payments restrictions and preferential trade areas) were unsuitable for consideration by Panels in WTO dispute settlement proceedings. In this regard, see William J. Davey, 'A Comment on Are the Judicial Organs of the World Trade Organization 
The more interesting question becomes what might constitute such a legal impediment? The Appellate Body specifically stated that it was 'express[ing] no view as to whether there may be other circumstances in which legal impediments could exist that would preclude a panel from ruling on the merits of the claims before it'. ${ }^{45}$ After taking that position, the Appellate Body then noted that the WTO case before it was distinct from the NAFTA case that Mexico wanted to bring in that there was (i) no overlap between the issues raised in the two cases (in particular, Mexico's claims in the NAFTA case were entirely NAFTA-based market-access claims); (ii) no ruling in the NAFTA case, i.e. no conflict possibility or issue such as res judicata; and (iii) no waiver of jurisdiction, which might occur given the NAFTA rules on choice of forum. ${ }^{46}$

The Appellate Body's mention of these issues raises obvious questions: What if a WTO Panel were faced with a situation where (i) there had been a prior ruling that raised concerns of conflict or res judicata; (ii) the issues in the WTO case were also present in a case before another tribunal; or (iii) the complaining party had arguably waived its right to initiate a WTO proceeding? We consider these questions only briefly since the issues underlying them were not actually present in the Soft Drinks case. It should be stressed that these questions raise essentially procedural issues and not more general substantive issues about how the WTO dispute settlement system should handle potential substantive conflicts with other international agreements. ${ }^{47}$

Overburdened?', in Efficiency, Equity, and Legitimacy: The Multilateral Trading System at the Millennium (Robert B. Porter, Pierre Sauvé, Arvind Subramanian, and Americo Beviglia Zampetti eds., Washington, DC: Brookings Institution Press 2001), pp. 329-333; William J. Davey, 'Has the WTO Dispute Settlement System Exceeded Its Authority?: A Consideration of Deference Shown by the System to Member Government Decisions and Its Use of Issue-Avoidance Techniques', 4(1) JIEL 79, 104-105 (2001). More generally, it is worth noting that the International Court of Justice typically does not decline to exercise jurisdiction where it exists. As explained by Rosenne, 'the Court has little freedom to decide whether to deal with a case submitted to it. Its function, its raison d'être, is to decide disputes that are submitted to it, and only essential deficiencies or overriding requirements of judicial propriety can lead it to refrain from determining a case.' Shabtai Rosenne, The Law and Practice of the International Court: 1920-1996, Volume II - Jurisdiction 842 (The Hague, Boston, London: Martinus Nijhoff Publishers 1997). This is, if anything, even more the case for the WTO system since it effectively has compulsory jurisdiction. The examples Rosenne gives where the ICJ has declined to rule on a case seem to relate to situations where no relief can be granted or none has been requested or where the matter is moot. Ibid. at 546-552. For consideration of issues such as mootness, non liquet, and the like in GATT/WTO practice, in the ICJ and in the US, see generally William J. Davey, 'Has the WTO Dispute Settlement System Exceeded Its Authority?: A Consideration of Deference Shown by the System to Member Government Decisions and Its Use of Issue-Avoidance Techniques', 4(1) JIEL 79 (2001).

45 Appellate Body Report, para. 54.

46 NAFTA article 2005.6 provides, subject to narrow exceptions, that '[o]nce dispute settlement procedures have been initiated under [NAFTA] or ... under the GATT, the forum selected shall be used to the exclusion of the other'. See also text accompanying notes 35-37, supra.

47 See generally Joost Pauwelyn, Conflict of Norms in Public International Law: How WTO Law Relates to Other Rules of International Law (New York: Cambridge University Press 2003); William J. Davey, 'The Quest for Consistency: Principles Governing the Interrelation of the WTO Agreements', in William J. Davey, Enforcing World Trade Rules: Essays on WTO Dispute Settlement and GATT Obligations (London: Cameron May 2006), p. 317. 


\subsection{Res judicata ${ }^{48}$}

As a technical matter, it is unlikely that the principle of res judicata would be applied by a WTO Panel, except where the prior 'judgment' was a WTO Panel/ Appellate Body report involving the same parties and issues. Even in that case, one might expect a Panel to simply rely on notions of finality or precedent to dispose of the case. ${ }^{49}$ Otherwise, it would seem that a decision by a non-WTO body purporting to interpret WTO obligations would be owed and would be given no deference in the WTO system. Indeed, DSU article 23 essentially requires WTO Members to take their WTO disputes exclusively to the WTO. ${ }^{50}$ The arguably more difficult case would arise where a decision by a tribunal had been made under a non-WTO agreement in respect of a provision identical to the WTO provision at issue. Such a situation is easy to imagine, especially as preferential trade agreements often incorporate GATT provisions by reference or restate them. Even in such a case, it would seem that res judicata would not apply. Even though the same parties would be involved, the underlying issue would be different - in one case, a WTO violation would be claimed; in the other case, a violation of some other agreement would be claimed. Even if the provisions at issue were identical, the setting in which the cases arose would be different, and to the extent that proper interpretation requires consideration of context and of the object and purpose of the agreement, it is inevitable that the WTO agreement and the other agreement would not be identical in those respects. Thus, since the same interpretative result would not be inevitable ${ }^{51}$ the claims could not be viewed as identical. Moreover, different remedies would typically be available and enforced in a different matter (i.e., in a multilateral, as opposed to a bilateral, setting).

48 Black's Law Dictionary, 1336-1337 (8th edn, 2004) defines 'res judicata' as ' 1 . An issue that has been definitively settled by judicial decision. 2. An affirmative defense barring the same parties from litigating a second lawsuit on the same claim, or any other claim arising from the same transaction or series of transactions and that could have been - but was not - raised in the first suit. The three essential elements are (1) an earlier decision on the issue, (2) a final judgment on the merits, and (3) the involvement of the same parties, or parties in privity with the original parties.' See also American Law Institute, Restatement Second, Judgments $\S \S 17,24,25,26$ (1982).

49 The Appellate Body has ruled that a claim rejected in the original Panel proceeding because a prima facie case had not been established may not be raised in a subsequent DSU article 21.5 proceeding, although a claim not considered for reasons of judicial economy could be raised. The Appellate Body relied on the principle of finality. EC-Bed Linen (Article 21.5-India), WT/DS141/AB/RW, paras. 78-100. It also referred by analogy to DSU article 17.14 , which requires parties to accept Appellate Body reports unconditionally.

50 European Communities - Measures Affecting Trade in Commercial Vessels, WT/DS301/R, adopted 20 June 2005; United States - Sections 301-310 of the Trade Act of 1974, WT/DS152/R, adopted 27 January 2000. Neither Panel report was appealed.

51 This point is made by the EC Court of Justice in European Economic Area, Opinion 1/91, [1991] ECR I-6084 (suggesting identical provisions in the EC and EEA treaties might be interpreted differently because of the different degree of economic integration contemplated by the two treaties). A similar situation would arguably arise in all cases involving the WTO agreement and some other international agreement. 
Hence, it seems unlikely that the conditions for res judicata as commonly understood would ever arise..$^{2}$

\subsection{Simultaneous proceedings}

If the foregoing conclusion on res judicata is correct, then the existence of another proceeding dealing with a related dispute would seem to be irrelevant. If the result of that proceeding would not have to be given effect, then the mere existence of the proceeding would not seem to be relevant. ${ }^{53}$ Considerations of comity, which arise in domestic legal systems would not seem relevant, particularly given the requirement that WTO Members bring their WTO disputes to the WTO dispute settlement system. ${ }^{54}$ It would obviously be desirable from the perspective of avoiding duplication of proceedings and conservation of resources if there were agreements negotiated as to how to allocate jurisdiction over disputes in respect of international agreements covering subjects in a way that multiple dispute settlement procedures might be expected to be invocable. But it is difficult to see how that can be done by the dispute settlement systems themselves. After all, how would they decide on who gets priority ${ }^{55}$ Does the WTO always win? Or, does it always defer $?^{56}$

\subsection{Waiver}

The most interesting of these questions is whether a WTO Member could waive its right to take a dispute over a matter to the WTO, typically by agreeing to go to the dispute settlement procedures of a preferential trade agreement to resolve certain matters. This would not violate DSU article 23 since the claim would technically arise under the preferential agreement, even though a substantially

52 Accord, Joost Pauwelyn, Editorial Comment: 'Adding Sweeteners to Softwood Lumber: The WTO-NAFTA “Spaghetti Bowl” is Cooking', 9 JIEL 197, 200-201 (2006). Brownlie also makes this point in respect of municipal and international proceedings, noting, inter alia, that the 'issues will have a very different aspect'. Ian Brownlie, Principles of International Law (Oxford: Oxford University Press, 5th edn, 1998), pp. 52-53. An analogy could be drawn to federal-court systems where it may sometimes be the case that, for example, a state court could not entertain a federal claim and vice versa. In such a situation, res judicata may not apply. American Law Institute, Restatement Second, Judgments $\S 26(1)$ (c) and Comment $c$ (1982). See also, ibid., § 25, Comment $e$.

53 This does not necessarily imply that the results of a non-WTO dispute settlement proceeding should not be considered and given appropriate weight by WTO Panels and the Appellate Body.

54 DSU, art. 23.

55 While useful, for example, it is not clear that the International Law Commission's Conclusions of the work of the Study Group on the 'Fragmentation of International Law: Difficulties arising from the Diversification and Expansion of International Law' (2006) provide any clear guidance. Should a traderelated environmental measure be viewed as subject to the trade regime or the environmental regime? Is it a trade measure or an environmental measure? Each position would seem to have valid arguments in its favor.

56 Pauwelyn argues for coordination, but is unclear how it can be achieved. Pauwelyn, supra note 52, at 201-202; Joost Pauwelyn, 'Choice of Jurisdiction: WTO and Regional Dispute Settlement Mechanisms: Challenges, Options and Opportunities' (2006), available at http://www.ictsd.org/dlogue/ 2006-05-30/dialogue_materials/Joost_Pauwelyn_speaker_notes.pdf (last visited 4 June 2008). 
identical claim would be available under the WTO agreements. To put the matter in concrete terms, if the Mercosur provision referred to in the Argentina Poultry case had been in force, ${ }^{57}$ should the Panel have enforced it by declining to rule on Brazil's WTO complaint? Or should the Panel have heard Brazil's claim and simply noted that Argentina might have a valid claim against Brazil under Mercosur for Brazil's pursuit of its claim in the WTO? On the one hand, a Panel could invoke the principle of good faith (it would arguably be an abus de droit to allow a party to violate its obligations $)^{58}$ or the rules of the Vienna Convention. ${ }^{59}$ On the other hand, a Panel has to be mindful that DSU article 23 was designed to strengthen the multilateral system and to promote the exclusive use of the WTO dispute settlement system for WTO disputes. It can be argued that the WTO system need not and should not concern itself with protecting claims of exclusive jurisdiction made by other systems, especially given that to do so could undermine the WTO system. This is particularly the case given that all WTO Members have an interest in how disputes over WTO issues are resolved. Allowing or encouraging Members to take WTO-related disputes to other fora, where the rest of the WTO Membership has no right to be heard seems unwise. Indeed, to give effect to a WTO Member's waiver of its right to invoke WTO dispute settlement also deprives other WTO Members of the third-party rights that they would otherwise enjoy. It is arguable that such a result should be possible only if approved in advance by the WTO Membership (e.g., through a waiver). ${ }^{60}$

While the issue is a close one, we lean toward the latter view. ${ }^{61}$ DSU article 23 would be undermined if disputes over WTO issues could not be brought to WTO dispute settlement, where all WTO Members can participate. While prior PTA (Preferential Trade Agreement) dispute settlement decisions on similar issues may be considered by the WTO Appellate Body and Panels, there should be no automatic deference. Indeed, why should one expect PTA dispute settlement systems,

57 See text accompanying notes 35-37, supra.

58 See generally Marion Panizzon, Good Faith in the Jurisprudence of the WTO (Oxford and Portland, OR: Hart Publishing 2006).

59 See, e.g., Vienna Convention on the Law of Treaties, art. 31.3(c) (context shall comprise any relevant rules of international law applicable in the relations between the parties). Pauwelyn argues that this provision is not really that useful since the phrase 'the parties' means all the parties, which will not be the case when regional trade agreements are at issue. Pauwelyn, supra note 56. He would instead argue that in the process of determining the applicable law, the Panel would conclude that the explicit agreement between the parties should be given effect. Ibid.

60 In this regard, the ILC Conclusions, supra note 55, are noteworthy. They state that when States enter into a treaty that may conflict with other treaties, they should try to settle the relationship issue, but that they cannot affect third-party rights in doing so. Conclusion 30.

61 Pauwelyn criticizes such a result on the grounds that the result would (a) go against the sovereign will of the parties (but one of the parties could have agreed, perhaps in bad faith admittedly, on the assumption that a WTO Panel would not decline jurisdiction and that it could agree to the exclusivity clause knowing the only sanction would be that imposed under the FTA); (b) waste resources (basically true); and (c) result in unpredictability in trade relations because of potential conflicts (also possible). Pauwelyn, supra note 56. 
which generally are more political and have no second-tier review, ${ }^{62}$ to produce superior decisions worthy of deference. Thus, given the multilateral interest and its superior dispute settlement system, the WTO should not automatically defer to decisions made by PTA dispute settlement systems on issues that also arise under WTO agreements and should not enforce provisions purporting to divest it of jurisdiction (absent a WTO-approved waiver).

\section{Can Panels consider or interpret other international agreements?}

In trying to convince the Appellate Body that the Panel should have declined to exercise its jurisdiction, Mexico cited the ruling by the Permanent Court of International Justice in the Factory at Chorzów case. ${ }^{63}$ In particular, it pointed to a passage where the Court expressed the view that a party cannot avail itself of the fact that the other party has not fulfilled an obligation if the first party has prevented it from doing so or prevented it from having access to a tribunal. ${ }^{64}$ This was not really the case here. The US was seeking to enforce a WTO obligation, and it had not prevented Mexico from complying with that obligation or from accessing the WTO dispute settlement system. Had the US argued that a case brought by Mexico should be referred to a NAFTA Panel when the US was preventing that from occurring, then the language in the Factory at Chorzów case would have been arguably relevant. In such a situation, for the Panel to decline to exercise jurisdiction would have meant that the complaining party had no redress. But that was not the case here.

In any event, in addressing this argument, the Appellate Body had occasion to write the following:

Even assuming, arguendo, that the legal principle reflected in the passage referred to by Mexico is applicable within the WTO dispute settlement system, we note that this would entail a determination whether the United States has acted consistently or inconsistently with its NAFTA obligations. We see no basis in the DSU for panels and the Appellate Body to adjudicate non-WTO disputes. Article 3.2 of the DSU states that the WTO dispute settlement system 'serves to preserve the rights and obligations of Members under the covered agreements, and to clarify the existing provisions of those agreements'. (emphasis added) Accepting Mexico's interpretation would imply that the WTO dispute settlement system could be used to determine rights and obligations outside the covered agreements. ${ }^{65}$

62 See David L. H. Morgan, 'Dispute Settlement Under PTAs: Political or Legal?', University of Melbourne Legal Studies Research Paper No. 341, available at http://ssrn.com/abstract=1203022 (last visited 7 October 2008).

63 Factory at Chorzów (Germany v. Poland) (Jurisdiction), PCIJ Series A, No. 9 (1927).

64 Appellate Body Report, para. 55 \& n.114.

65 Appellate Body Report, para. 56. 
This statement seems incorrect and inconsistent with prior Appellate Body precedent. ${ }^{66}$ While a Panel might in the circumstance envisaged by the Appellate Body have to make a determination for its own purposes as to whether the US was acting consistently with NAFTA, such a determination would not be a determination of rights under NAFTA; it would only be a preliminary step in making a WTO ruling. The situation would be like that in EC-Bananas III, where the Panel (and the Appellate Body) had to take a position on the meaning of the Lomé Convention in order to rule on whether an EC measure was covered by the so-called Lomé waiver, which permitted EC measures 'required' by the Lomé Convention. ${ }^{67}$ Such action would not entail a determination of rights under another agreement. Such a determination would have to be made pursuant to the terms of the agreement in question using whatever dispute resolution procedures it provided. ${ }^{68}$ Thus, the WTO system would not be 'used to determine rights and obligations outside the covered agreements'.

In short, this paragraph in the Appellate Body report was only dicta to begin with and seems not to have been well-expressed dicta at that. While WTO Panels and the Appellate Body cannot definitively determine rights and obligations under non-WTO agreements, absent some provision so providing, they can refer to and analyze such agreements to the extent it is necessary to determine rights and obligations under the WTO agreements. ${ }^{69}$

\section{How can the interests of non-party WTO Members be protected in disputes under regional agreements?}

The WTO is a multilateral contract that provides rights and obligations to its Members. Like other multilateral contracts, the WTO contract contains several clauses designed to ensure that subsequent agreements between subsets of

66 Pauwelyn essentially agrees. See Pauwelyn, supra note 56.

67 The Appellate Body stated that it had 'no alternative' but to do as the Panel had done, i.e. 'examine the provisions of the Lomé Convention ourselves in so far as necessary to interpret the Lomé Waiver'. Its examination of the meaning of the Convention covered several pages in its report. European Communities - Regime for the Importation, Sale and Distribution of Bananas, WT/DS27/AB/R, paras. 167-178, adopted 25 September 1997.

68 It should be noted that it is possible that a subsequent determination under the non-WTO agreement will be inconsistent with the decision in respect of that agreement made by the WTO body. That would be unfortunate, but such a possibility seems inevitable. It is similar to the situation in the United States where a federal court may have to interpret state law in the absence of state-court precedent. When it does so, it is always possible that a subsequent state-court decision on the issue may be inconsistent with the federal-court decision.

69 See also United States - Import Prohibition of Certain Shrimp and Shrimp-Containing Products, WT/DS58/AB/R, adopted 6 November 1998 (referring to other international agreements to assist in interpretation of GATT, at para. 168 - without any suggestion that it was definitively interpreting those agreements); United States - Standards for Reformulated and Conventional Gasoline, WT/DS2/AB/R, adopted 20 May 1996 (GATT not to be interpreted in 'clinical isolation' from public international law, at page 17). 
Members, including but not limited to regional agreements, do not harm the interests of non-party WTO Members.

\subsection{General WTO principles}

The WTO agreements contain two general principles designed to protect the interests of non-parties to subsequent agreements: the most-favored-nation (MFN) principle and the transparency rule. The MFN principle, which is found in the three WTO agreements (GATT Article I, GATS Article II, and TRIPS Article 4), provides that any trade benefit accorded by a WTO Member to another Member must be extended to all other WTO Members immediately and unconditionally. The transparency rule, which is also found in the three WTO agreements (GATT Article X, GATS Article III, and TRIPS Article 63), ensures that all laws and regulations affecting trade are known to all WTO Members.

In addition, the WTO Dispute Settlement Understanding ensures that, in case of a WTO trade dispute, Members that are not original parties to the dispute may either join in the consultations (DSU article 4.11) or become third parties in the Panel process (DSU article 10). There are good economic reasons to give to WTO Members the opportunity to become involved in disputes to which they are not original parties. The main rationale is that the resolution of disputes tends to generate externalities that affect third parties. Although such externalities may be positive, third parties may be especially concerned when they are negative, as, for instance, when the resolution of a dispute between two Members results in decreased exports by, or increased imports to, a third Member. ${ }^{70}$ At the same time, there is some evidence that the involvement of third parties in WTO disputes may impose a cost on the dispute settlement system because their participation tends to undermine early settlement and to lengthen the formal proceedings. ${ }^{71}$

Drawing on the work by Horn and Mavroidis, ${ }^{72}$ which examines all WTO disputes for the period 1995-2006, it appears clearly that the possibility to join in consultations or to become a third party is particularly important for smaller WTO Members. Using the distinction of Horn-Mavroidis between G2 (the European Communities and the United States) and non-G2 Members, we have used their data to compute the involvement of non-G2 Members in the different steps of trade disputes. It turns out that the non-G2 account for $58 \%$ of the original parties seeking consultations, which almost exactly equals their share in world trade during the period. By contrast, these countries account for $81 \%$ of the

70 See Chad Bown, 'MFN and the Third-Party Economic Interests of Developing Countries in GATT/ WTO Dispute Settlement', in Transcending the Ostensible: Developing Countries in the WTO Legal System (Chantal Thomas and Joel Trachtman eds., Oxford: Oxford University Press 2009).

71 See Marc Busch and Eric Reinhardt, 'Three's a Crowd: Third Parties and WTO Dispute Settlement', 58(3) World Politics 446-477 (2006).

72 See Henrik Horn and Petros C. Mavroidis, 'The WTO Dispute Settlement System 1995-2006: Some Descriptive Statistics', IFN Working Paper No. 740, Research Institute of Industrial Economics, Stockholm (2008). 
parties joining in consultations at a later stage and $86 \%$ of third parties involved at the Panel stage. In other words, non-G2 Members tend to join in consultations or to become third parties at the Panel stage much more often than they act as original complainants.

\subsection{Rules pertaining to regional agreements}

One major exception to the MFN principle is the possibility for WTO Members to form preferential trade agreements in goods (GATT Article XXIV) or in services (GATS Article V). However, this exception is subject to a number of conditions designed to ensure that the interests of non-party WTO Members are protected.

These conditions fall under two categories. First, Members of a preferential agreement cannot raise the overall level of barriers to trade against non-party WTO Members above the level existing prior to such agreements (GATT Article XXIV.5 and GATS Article V.4). Second, preferential trade agreements must be notified to the WTO, and WTO Members may examine them with a view to 'make ... recommendations to [the] parties as they may deem appropriate' ${ }^{73}$ In principle, therefore, non-party WTO Members seem to enjoy review rights over regional trade agreements. In practice, however, such rights have been severely curtailed by the vague language used in GATT Article XXIV and the absence of a proper mechanism to review preferential trade agreements. ${ }^{74}$

There have been three attempts to improve the rules pertaining to regional trade agreements. The 1994 Understanding on the Interpretation of GATT Article XXIV tightened a bit the language of Article XXIV and granted power to the Dispute Settlement Body to review the consistency of preferential agreements with the WTO. Shortly after the WTO Agreement came into force, the General Council established a permanent Committee on Regional Trade Agreements (CRTA), to which preferential agreements must be notified. The 2006 General Council Decision on the Transparency Mechanism for Regional Trade Agreements further sought to improve the transparency provisions of GATT Article XXIV and GATS Article $\mathrm{V}$ with the obligation for RTA parties to provide detailed information to the CRTA. So far, however, these attempts have not succeeded in adding much discipline to the system. ${ }^{75}$

One area where GATT provisions were, and WTO provisions remain, totally silent is regional dispute settlement mechanisms. At the moment, each preferential trade agreement is free to set its own rules, which may or may not, therefore, grant non-party WTO Members the possibility to take part in dispute settlement proceedings between parties. In practice, no RTA does.

73 GATT Article XXIV.7(a). GATS Article V.7(c) contains a similar provision.

74 See Petros C. Mavroidis, 'If I Don't Do It, Somebody Else Will (or Won't)', 40(1) Journal of World Trade 187-214 (2006).

75 See Jagdish Bhagwati, Termites in the Trading System: How Preferential Agreements Undermine Free Trade (New York: Oxford University Press 2008). 


\subsection{Regional dispute settlement: impact on the smaller parties}

Many of the recent regional trade agreements are between the G2 and non-G2 WTO Members. As of 10 August 2008, the EC and the US had been parties to agreements notified to the WTO and entered into force with, respectively, 13 and 9 (non-G2) WTO Members, all of which were significantly smaller than their G2 partner. Canada, the largest US RTA partner, is four times smaller than the US in terms of world trade. ${ }^{76}$ Similarly, Mexico, the largest EC regional partner is six times smaller than the EC.

The asymmetry (in terms of economic size) between the G2 and their regional trade partners implies that the latter may be at a disadvantage in regional compared to WTO dispute settlement. Two reasons justify this likelihood. First, regional trade partners cannot form coalitions with other WTO Members to act as co-complainants and increase their bargaining power, as they do in WTO trade disputes. As it has been argued, 'one of the virtues of the DSU is that it offers a weaker state the possibility of coalition-building and the formal involvement of the Members of that coalition in the dispute' ${ }^{77}$ Second, as the original Mexico-US NAFTA dispute shows, the smaller partner may not be able to even obtain adjudication of regional disputes since - contrary to the WTO dispute settlement system - regional dispute mechanisms may not be automatic. One would expect, therefore, that when regional trade agreements leave the choice of forum to complainants, as some do, smaller partners would choose the WTO track while the EC and the US would choose the regional track. Unfortunately, the prediction about the choice of forum is difficult to test empirically. Instead, partial evidence will be provided about the use of forum.

As of 20 August 2008, the US had been a complainant in 11 WTO disputes against regional trade partners, all with NAFTA partners: six against Mexico and five against Canada. The US was also a respondent in 21 cases, again all with NAFTA partners: 14 brought by Canada and seven by Mexico. During the same period, only three NAFTA Chapter 20 disputes were adjudicated: one with the US as complainant (against Canada) and two with the US as respondent (brought by Mexico). Hence, there have been altogether 35 formal trade disputes between the three NAFTA partners involving the US, 32 resolved by the WTO dispute settlement process and three by the NAFTA process. This would seem to suggest that the WTO is, by far, the main forum for adjudicating trade disputes between NAFTA partners. Note, however, that this statement cannot be construed as saying that complainants tend to choose the WTO over the NAFTA dispute

76 Imports plus exports. Figures for 2007 taken from the WTO website, http://www.wto.org/ (last visited 7 October 2008).

77 Peter Drahos, 'The Bilateral Web of Trade Dispute Settlement', Paper for the workshop on 'WTO Dispute Settlement and Developing Countries: Use, Implications, Strategies, Reforms', University of Wisconsin at Madison, 20-21 May 2005. 
mechanism since we have examined all trade disputes rather than only those where a choice of forum was feasible.

The contrast with the EC is striking. As of 20 August 2008, the EC had been a complainant in only two WTO disputes against regional trade partners - both against Mexico - and a respondent in only three cases - two with Norway and one with Chile. Unfortunately, there is no public information available on actual regional dispute-settlement instances between the EC and its trading partners, but the number appears to be extremely limited. ${ }^{78}$

Hence, the earlier finding that 'most dispute settlement provisions in RTAs do not seem to have been used, beyond those that simply provide for consultations ${ }^{79}$ seems still valid. The difficult question, obviously, is whether this situation will continue to prevail in the future despite the proliferation of regional trade agreements. There are essentially two opposite views. One holds that WTO dispute settlement is intrinsically superior to RTA dispute settlement, and therefore that it 'is likely to survive and prosper in a world with an ever increasing number of RTAs' ${ }^{80}$ The other argues, instead, that the proliferation of RTAs and their associated dispute settlement mechanisms will ultimately weaken the WTO and favor the large trading countries at the expense of weaker actors.

\subsection{Regional dispute settlement: impact on non-parties}

A prudent course of action should recognize that regional dispute settlement poses a problem not only to the smaller, weaker parties, but also to third parties, and seek to introduce reforms to minimize the risk of weakening the multilateral system. Regarding the problem for third parties, Peter Drahos cogently argues:

[the] choice-of-forum provisions do not sit very comfortably with the goal of strengthening the multilateral trading system. WTO members are meant to have recourse to the DSU when they decide to pursue a remedy for a breach of a WTO agreement. There are good reasons in principle to encourage parties to use the DSU. When parties resolve a trade dispute that requires a determination of obligation in one or more of the covered agreements of the WTO they deliver a public good for other members, assuming that the dispute results in a greater certainty of the interpretation of the rules. Where an infringing state brings a measure into conformity with an obligation it has under a covered agreement it will be of benefit to all other members by virtue of the MFN principle. In short,

78 With one exception, all the pre-2000 EC RTAs used a diplomatic, rather than a quasi-judicial, approach to dispute settlement. The option of having recourse to arbitration is normally available provided both parties agree. The EC-Mexico free-trade agreement marked the EC shift towards a quasijudicial model of dispute adjudication. See Ignacio Garcia Bercero, 'Dispute Settlement in European Union Free Trade Agreements: Lessons Learned?', in Regional Trade Agreements and the WTO Legal System (Lorand Bartels and Federico Ortino eds., Oxford: Oxford University Press 2006).

79 William J. Davey, 'Dispute Settlement in the WTO and RTAs: A Comment', in Regional Trade Agreements and the WTO Legal System (Lorand Bartels and Federico Ortino eds., Oxford: Oxford University Press 2006), p. 354.

80 Ibid. at p. 357. 
the third party benefits of a bilateral dispute in a multilateral regime under a multilateralized dispute mechanism are considerable. The same cannot be said of bilateral dispute resolution proceedings. ${ }^{81}$ (Emphasis added and original footnote suppressed).

Once again, it is the fact that dispute resolution generates externalities, which provides a powerful argument in favor of giving WTO Members the opportunity to become involved in disputes to which they are not original parties.

How then should regional dispute settlement mechanisms be reformed? One possible avenue is to start from the distinction between 'single breach' and 'double breach', where the former refers to situations where a state breaches an obligation it has under either the WTO or a regional agreement, while the latter indicates situations where the state breaches an obligation it has under both agreements. In a case of double breach, the complaining party may be allowed to choose the forum. Using this distinction, it has been suggested that regional dispute settlement provisions should include the requirement that parties take their disputes to the WTO in the case of double breach. ${ }^{82}$

We suggest a different approach, which does not distinguish between single and double breach. We propose that the WTO impose the requirement that all regional dispute settlement systems contain provisions giving non-party WTO Members third-party rights in regional disputes. This would ensure greater transparency of regional dispute settlement and enable third parties to claim their rights, possibly through WTO action. In addition, it might help make PTA dispute settlement systems more balanced, at least where there is considerable disparity in the economic power of the parties, as is often the case.

81 Peter Drahos, 'The Bilateral Web of Trade Dispute Settlement', Paper for the workshop on 'WTO Dispute Settlement and Developing Countries: Use, Implications, Strategies, Reforms', University of Wisconsin at Madison, 20-21 May 2005, p. 11.

82 See, for instance, Peter Drahos, 'The Bilateral Web of Trade Dispute Settlement', Paper for the workshop on 'WTO Dispute Settlement and Developing Countries: Use, Implications, Strategies, Reforms', University of Wisconsin at Madison, 20-21 May 2005. 